\title{
Osteoporotic vertebral compression fracture - Treatment with kyphoplasty and vertebroplasty
}

\section{FrATURA VERTEBRAL OSTEOPORÓtICA - TRATAMENTO COM CIFOPLASTIA OU VERTEBROPLASTIA}

\author{
Authorship: Brazilian Medical Association (AMB) \\ Participants: Wanderley Marques Bernardo ${ }^{1}$, Mauricio Anhesini ${ }^{1}$, Renata Buzzini ${ }^{1}$
}

Final draft: December 5, 2017

${ }^{1}$ Associação Médica Brasileira (AMB), São Paulo, SP, Brazil

The Guidelines Project, an initiative of the Brazilian Medical Association, aims to combine information from the medical field in order to standardize procedures to assist the reasoning and decision-making of doctors.

The information provided through this project must be assessed and criticized by the physician responsible for the conduct that will be adopted, depending on the conditions and the clinical status of each patient.

\section{EvidenCe COLLECTION METHOD}

This guideline followed the standard of a systematic review with evidence retrieval based on the evidence-based medicine $(\mathrm{EBM})$, so that clinical experience is integrated with the ability to critically analyze and apply scientific information rationally, thus improving the quality of medical care.

We used the structured mode of formulating questions synthesized by the acronym PICO, where P stands for patients with osteoporotic vertebral fracture, I refers to intervention using kyphoplasty, C stands for comparison with vertebroplasty and $\mathrm{O}$ stands for the outcomes of efficacy and adverse events.

By raising a relevant question related to the proposed topic, we identified, based on the structured question, the keywords that formed the basis of the search for evidence in the databases: Medline-Pubmed, Embase Cochrane Library. The studies had their abstracts reviewed and after applying the eligibility criteria (inclusion and exclusion), 15 articles were selected in order to answer the clinical doubt (Annex I).

\section{Clinical question}

Does kyphoplasty bring any benefit to patients presenting osteoporotic vertebral compression fractures compared to vertebroplasty?

\section{Grades of Recommendation AND LeVels OF EVIDENCE}

- A: Experimental or observational studies of higher consistency.
- B: Experimental or observational studies of lower consistency.

- C: Case reports / non-controlled studies.

- D: Opinion without critical evaluation, based on consensus, physiological studies or animal models.

\section{Objective}

The purpose of this evaluation is to estimate the benefit and risk of kyphoplasty compared to vertebroplasty in the treatment of patients with osteoporotic vertebral compression fractures.

\section{INTRODUCTION}

The incidence of vertebral fragility fractures increases with age. Vertebral fractures lead to pain, functional disability and decreased quality of life, which can last for several years and can also affect mortality. A patient with acute fracture should be examined for diagnosis using radiology. In case of a low energy fracture, osteoporosis should be suspected and investigated. If the pain treatment fails, vertebroplasty or kyphoplasty may be considered. In the rare case of neurological impairment or unstable fractures, surgical treatment should be considered. After vertebral fragility fractures, the risk of new fractures is high and secondary preventive measures should be used. The best evidence for secondary prevention is currently the medical treatment of osteoporosis.

Vertebroplasty is usually performed through a special needle that slowly injects bone cement percutaneously through each side of the pedicle into the vertebral body. 
Kyphoplasty uses two small incisions and a probe placed in the vertebral space at the fracture site. The bone is drilled and a balloon is inserted on each side. The balloons are inflated with contrast (to facilitate X-ray image orientation) and expanded to the desired height, and then removed. The spaces created by the balloons are filled with bone cement.

The results of both forms of treatment are usually measured in relation to quality of life, pain level and recurrence of fractures.

\section{Data extraction}

In 100 adult patients with pain and confirmed diagnosis of osteoporosis and thoraco-lumbar vertebral compression fractures, balloon kyphoplasty (50) was compared to percutaneous needle vertebroplasty (50). Operating time (44 \pm 4.4 minutes vs. $46.2 \pm 4.5$ minutes) and volume of bone cement $(4.91 \pm 0.65 \mathrm{~mL}$ vs. $5.56 \pm 0.62 \mathrm{~mL})$ were significantly lower in patients treated with kyphoplasty. However, the pain (VAS) score was similar between the two treatment modalities at the 3-day and 6-month follow-up. ${ }^{1,2}(\mathbf{B})$

In 404 adult patients with osteoporotic vertebral fractures (T5 to L5), and clinical (1 to 3 points of acute pain) and imaging (radiography, tomography or resonance) signs of compression, balloon kyphoplasty (199) was compared with percutaneous vertebroplasty (205). Follow-up lasted 3 to 24 months. There are no significant differences between the two treatment modalities regarding the outcomes of quality of life (SF-36 and EQ-5D), low back pain, dysfunction score and new fractures. There was only less extravasation of bone cement in the kyphoplasty procedure compared to vertebroplasty ( $73 \%$ vs. $82 \%$, respectively). ${ }^{3}(\mathbf{B})$

\section{ReCOMmEnDATION}

In patients with osteoporotic vertebral compression (symptomatic) fractures, the use of kyphoplasty compared to vertebroplasty after 3 to 24 months produces a slight reduction in surgical time and volume of bone cement. However, it does not determine any difference in the risk of recurrence of fractures, pain level, quality of life and level of dysfunction (evidence with a high risk of bias - B).

\section{Conflict of Interest}

The authors state that there is no conflict of interest regarding this review.

\section{REFERENCES}

1. Liu JT, Li CS, Chang CS, Liao WJ. Long-term follow-up study of osteoporotic vertebral compression fracture treated using balloon kyphoplasty and vertebroplasty. J Neurosurg Spine. 2015; 23(1):94-8.

2. Liu JT, Liao WJ, Tan WC, Lee JK, Liu CH, Chen YH, et al. Balloon kyphoplasty versus vertebroplasty for treatment of osteoporotic vertebral compression fracture: a prospective, comparative, and randomized clinical study. Osteoporos Int. 2010; 21(2):359-64.

3. Dohm M, Black CM, Dacre A, Tillman JB, Fueredi G; KAVIAR investigators A randomized trial comparing balloon kyphoplasty and vertebroplasty for vertebral compression fractures due to osteoporosis. AJNR Am J Neuroradiol. 2014; 35(12):2227-36

4. Yang EZ, Xu JG, Huang GZ, Xiao WZ, Liu XK, Zeng BF, et al. Percutaneous vertebroplasty versus conservative treatment in aged patients with acute osteoporotic vertebral compression fractures: a prospective randomized controlled clinical study. Spine (Phila Pa 1976). 2016; 41(8):653-60.

5. Chen D, An ZQ, Song S, Tang JF, Qin H. Percutaneous vertebroplasty compared with conservative treatment in patients with chronic painful osteoporotic spinal fractures. J Clin Neurosci. 2014; 21(3):473-7.

6. Yi X, Lu H, Tian F, Wang Y, Li C, Liu H, et al. Recompression in new levels after percutaneous vertebroplasty and kyphoplasty compared with conservative treatment. Arch Orthop Trauma Surg. 2014; 134(1):21-30.

7. Farrokhi MR, Alibai E, Maghami Z. Randomized controlled trial of percutaneous vertebroplasty versus optimal medical management for the relief of pain and disability in acute osteoporotic vertebral compression fractures. J Neurosurg Spine. 2011; 14(5):561-9.

8. Klazen CA, Lohle PN, de Vries J, Jansen FH, Tielbeek AV, Blonk MC, et al. Vertebroplasty versus conservative treatment in acute osteoporotic vertebral compression fractures (Vertos II): an open-label randomised trial. Lancet. 2010; 376(9746):1085-92.

9. Longo UG, Loppini M, Denaro L, Brandi ML, Maffulli N, Denaro V. The effectiveness and safety of vertebroplasty for osteoporotic vertebral compression fractures. A double blind, prospective, randomized, controlled study. Clin Cases Miner Bone Metab. 2010; 7(2):109-13.

10. Rousing R, Hansen KL, Andersen MO, Jespersen SM, Thomsen K, Lauritsen JM. Twelve-months follow-up in forty-nine patients with acute/semiacute osteoporotic vertebral fractures treated conservatively or with percutaneous vertebroplasty: a clinical randomized study. Spine (Phila Pa 1976). 2010; 35(5):478-82..

11. Kallmes DF, Comstock BA, Heagerty PJ, Turner JA, Wilson DJ, Diamond $\mathrm{TH}$, et al. A randomized trial of vertebroplasty for osteoporotic spinal fractures. N Engl J Med. 2009; 361:569-79.

12. Rousing R, Andersen MO, Jespersen SM, Thomsen K, Lauritsen J. Percutaneous vertebroplasty compared to conservative treatment in patients with painful acute or subacute osteoporotic vertebral fractures: three-months follow-up in a clinical randomized study. Spine (Phila Pa 1976). 2009; 34(13):1349-54.

13. Voormolen MH, Mali WP, Lohle PN, Fransen H, Lampmann LE, van der Graaf Y, et al. Percutaneous vertebroplasty compared with optimal pain medication treatment: short-term clinical outcome of patients with subacute or chronic painful osteoporotic vertebral compression fractures. The VERTOS study. AJNR Am J Neuroradiol. 2007; 28(3):555-60.

14. Oxford Centre for Evidence-based Medicine - Levels of Evidence. Available from: http://www.cebm.net/oxford-centre-evidence-based-medicine-levelsevidence-march-2009/.

15. Guyatt G, Gutterman D, Baumann MH, Addrizzo-Harris D, Hylek EM, Phillips B, et al. Grading strength of recommendations and quality of evidence in clinical guidelines: report from an American college of chest physicians task force. Chest. 2006; 129(1):174-81. 


\section{AnNex I}

\section{Structured question}

The clinical question was structured based on the PICO components: P (patient), I (intervention), C (comparison), $\mathrm{O}$ (outcome).

- $\mathbf{P}$ - Osteoporotic vertebral fracture

- I - Kyphoplasty

- C - Vertebroplasty

- O - Efficacy and adverse events

\section{Search strategy}

The scientific databases consulted were PubMed-Medline and Cochrane. A manual search was performed based on references of the reviews (narrative or systematic), as well as the selected studies.

\section{PubMed-Medline}

- (Osteoporosis OR Osteoporoses) AND (Vertebroplasty OR Kyphoplasty) AND Random*

\section{Articles retrieved}

- In all, 148 articles were retrieved from Medline. Of these, 13 were selected based on title and abstract.

- After analysis of the full texts and abstracts, three RCTs were included for assessment. ${ }^{1-3}$

- The main reasons for excluding 10 articles $^{4-13}$ were: RCT that did not compare vertebroplasty with kyphoplasty, as well as study protocols.

- The results of the RCTs included will be displayed individually first.

\section{Inclusion criteria for selected studies}

The selection of the studies, the evaluation of the titles and abstracts obtained after applying the search strategy in the consulted databases was conducted by two researchers in an independent and blinded manner, strictly following the inclusion and exclusion criteria, so that only potentially relevant articles would be retrieved. If title and abstract were not clear enough, the article was read in full.

\section{Study design}

Randomized controlled trials with no limit applied for year of publication.

\section{Language}

We included studies available in Portuguese, English, French or Spanish.

\section{According to publication}

Only full-text studies were considered for critical assessment.

\section{Evidence selected based on critical assessment}

The strength of the evidence from the RCTs was defined taking into account the study design and corresponding bias risks (randomization, blinding, loss, prognostic characteristics, outcomes, intention-to-treat analysis, sample calculation), the results of the analysis (magnitude and precision), relevance and applicability (Oxford/GRADE). ${ }^{14,15}$

\section{Data analysis and extraction}

Results obtained from included studies presented as means and standard deviations were: pain improvement, operative time, cement volume and extravasation, quality of life scores and dysfunction score. The results expressed in absolute numbers (absolute risk and NNT) were related to fracture risk. The confidence level was $5 \%$.

All results are available as tables in Annex II.

\section{Description of evidence}

The available evidence will follow a sequence to be displayed:

- According to results of study retrieval and selection.

- According to the description of the characteristics and results of the individual studies included.

- The results comprise the number of patients, outcome, magnitude (mean difference or NNT), and precision (standard deviation and 95CI).

\section{Recommendation}

The global evidence summary will be elaborated considering the evidence described:

- The strength (Oxford/GRADE $)^{14,15}$ will be estimated as $1 \mathrm{~b}$ or $1 \mathrm{c}$ (grade $\mathrm{A}$ ) or strong, and $2 \mathrm{a}, 2 \mathrm{~b}$ or $2 \mathrm{c}$ (grade B) or moderate, weak or very weak.

- The strongest evidence will be considered. 


\section{AnNex II - Results from the STUdies included for ASSESSMENT}

\section{TABLE 1 Description of study characteristics.}

\begin{tabular}{|c|c|c|c|c|c|}
\hline Studies & Population (N) & Intervention (N) & Comparison $(\mathrm{N})$ & Outcome & Follow-up time \\
\hline $\begin{array}{l}\text { Liu et al. }{ }^{2} \\
\text { Liu et al. }{ }^{1}\end{array}$ & $\begin{array}{l}\text { Patients with pain and diagnosis of } \\
\text { osteoporosis and vertebral compression } \\
\text { fractures (VCFs) at the thoracolumbar } \\
(\mathrm{T}-\mathrm{L}) \text { junction }(\mathrm{T} 12-\mathrm{L} 1)(\mathrm{N}=100)\end{array}$ & $\begin{array}{l}\text { Balloon kyphoplasty } \\
(\mathrm{N}=50)\end{array}$ & $\begin{array}{l}\text { Percutaneous needle } \\
\text { vertebroplasty }(\mathrm{N}=50)\end{array}$ & $\begin{array}{l}\text { Pain - VAS Score } \\
\text { Operating time } \\
\text { Volume of } \\
\text { bone cement }\end{array}$ & 60 months \\
\hline Dohm et al. ${ }^{3}$ & $\begin{array}{l}\text { Participants included had osteoporosis } \\
\text { and } 1 \text { to } 3 \text { points of acute pain due to } \\
\text { VCFs in } T 5 \text { to } L 5 \text { vertebrae. } \\
\text { Patients with more than } 3 \text { acute fractures, } \\
\text { with VCFs for more than } 6 \text { months, were } \\
\text { excluded ( } N=404 \text { ) }\end{array}$ & $\begin{array}{l}\text { Balloon kyphoplasty } \\
(\mathrm{N}=199)\end{array}$ & $\begin{array}{l}\text { Percutaneous } \\
\text { vertebroplasty with } \\
\text { direct injection of bone } \\
\text { cement into the site of } \\
\text { fracture without the aid } \\
\text { of a balloon }(\mathrm{N}=205)\end{array}$ & $\begin{array}{l}\text { Lumbar pain, } \\
\text { quality of life (SF-36, } \\
\text { EQ-5D), dysfunction } \\
\text { (ODI score), } \\
\text { extravasation of } \\
\text { bone cement }\end{array}$ & $\begin{array}{l}3,12 \text { and } \\
24 \text { months }\end{array}$ \\
\hline
\end{tabular}

VCFs: vertebral compression fractures.

\section{TABLE 2 Description of study biases.}

\begin{tabular}{|c|c|c|c|c|c|c|c|c|c|}
\hline Study & Question & Randomization & Allocation & Blinding & Losses & Prognosis & Outcomes & ITT Analysis & Sample calculation \\
\hline Liu et al. ${ }^{2}$ & Yes & Yes & No & No & No & Yes & No & No & Yes \\
\hline $\begin{array}{l}\text { Dohm } \\
\text { et al. }{ }^{3}\end{array}$ & Yes & Yes & Yes & No & No & Yes & Yes & No & Yes \\
\hline
\end{tabular}

ITT: intention to treat

\section{TABLE 3 Description of study results. ${ }^{1,2}$}

\begin{tabular}{llll} 
Outcomes & Kyphoplasty & Vertebroplasty & Significance \\
\hline Operating time & $44.0 \pm 4.4$ minutes & $46.2 \pm 4.5$ minutes & $\mathrm{P} \leq 0.05$ \\
\hline Volume of bone cement (PMMA) & $4.91 \pm 0.65 \mathrm{~mL}$ & $5.56 \pm 0.62 \mathrm{~mL}$ & $\mathrm{P} \leq 0.05$ \\
\hline Pain - VAS Score, 6 months & $2.6 \pm 0.6$ & $2.6 \pm 0.6$ & $\mathrm{NS}$ \\
\hline Pain - VAS Score, 3 days & $2.6 \pm 0.6$ & $2.3 \pm 0.5$ & $\mathrm{NS}$ \\
\hline
\end{tabular}

PMMA: polymethyl methacrylate; VAS: Visual Analogue Scale; NS: not significant.

\section{TABLE 4 Description of results for study 3 .}

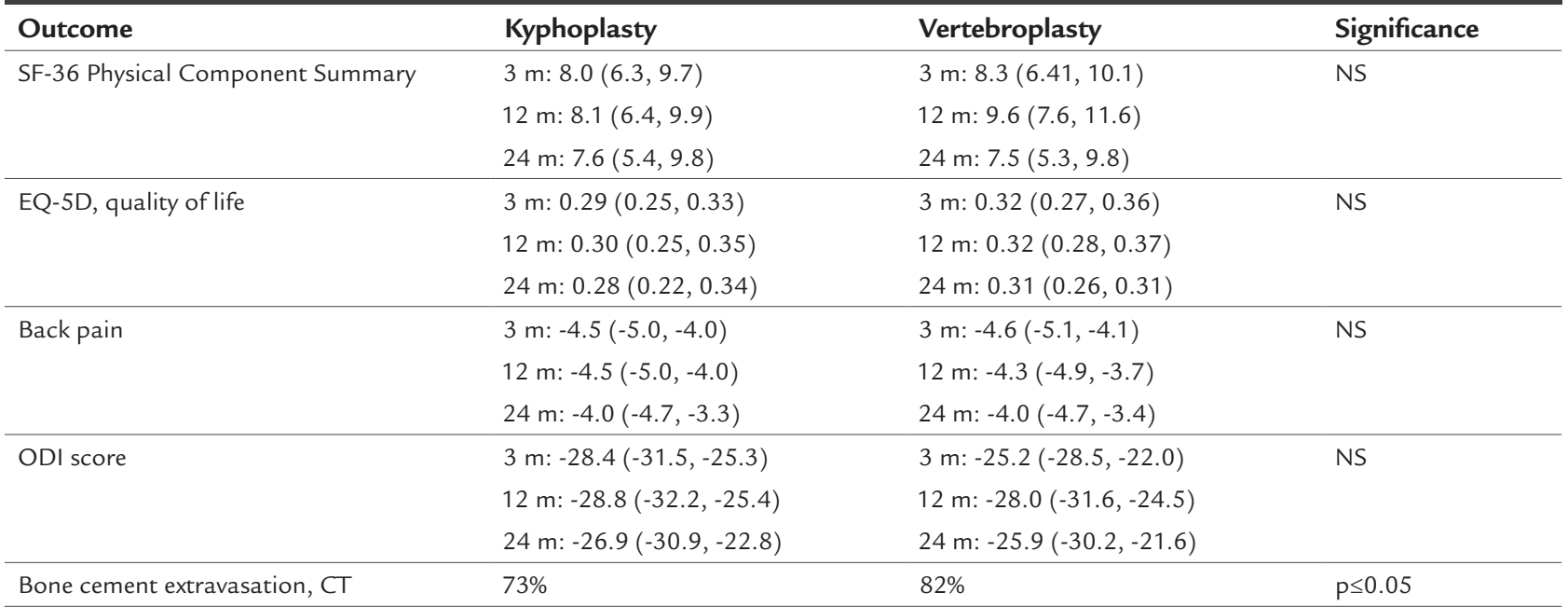

\section{c) (7) (8)}

This is an open-access article distributed under the terms of the Creative Commons Attribution License. 